\title{
One-Pot Three-Component Synthesis of N-Arylmethyl-4-(7-cyclohepta-1,3,5-trienyl)anilines
}

\author{
Lidia P. Yunnikova, Tatiana A. Akentieva, Tatiana V. Makhova \\ Perm State Agricultural Academy, Perm, Russia \\ Email: yunnikova@yahoo.com
}

Received April 2, 2013; revised April 30, 2013; accepted May 3, 2013

Copyright (C) 2013 Lidia P. Yunnikova et al. This is an open access article distributed under the Creative Commons Attribution License, which permits unrestricted use, distribution, and reproduction in any medium, provided the original work is properly cited.

\begin{abstract}
We report a one-pot three-component synthesis of $\mathrm{N}$-arylmethyl-4-(7-cyclohepta-1,3,5-trienyl)anilines by using various aromatic imines, tropylium tetrafluoroborate, and sodium tetrahydroborate in the presence of imidazole as activator.
\end{abstract}

Keywords: Imines; Tropylium Tetrafluoroborate; Sodium Tetrahydroborate;

N-Arylmethyl-4-(7-cyclohepta-1,3,5-trienyl)anilines

\section{Introduction}

Nitrogen-containing compounds with the 1,3,5-cycloheptatriene fragment have a marked biological action [1, $2]$. The use of tropylium salts (tetrafluoroborate or perchlorate) is a method to introduce the 1,3,5-cycloheptatriene cycle into aniline molecules and into its substituted molecules. Anion in a tropylium salt influences the N-[3] or C-[1] tropylation process of aniline, of arylamines or of $\mathrm{N}$-substituted anilines, and a yield of final products.

Interaction between tropylium tetrafluoroborate and aniline or arylamines proceeds as N-tropylation of amino-group with subsequent transformation to 8-aryl-8azaheptafulvenes [3]. Reaction with N,N,-dimethylaniline proceeds as C-tropylation; however, the expected 7-(4$\mathrm{N}, \mathrm{N}$-dimethylaminophenyl)-1,3,5-cycloheptatriene was not educed. Its isomer, namely 3-(4-N,N-dimethylaminophenyl)-1,3,5-cycloheptatriene (18\% yield), was identified from a mixture of reaction products [4].

A good result was obtained after replacement of tetrafluoroborate with tropylium perchlorate to react with $\mathrm{N}$, $\mathrm{N}$-dimethylaniline or with aniline; this reaction is known to proceed as C-tropylization and enables educing 7(4-N,N-dimethylaminophenyl)-1,3,5-cycloheptatriene (up to $76 \%$ yield), or 7-(4-aminophenyl)-1,3,5-cycloheptatriene (up to $82 \%$ yield). The latter compound has a marked antimycobacterial action against Staphylococcus aureus, Staphylococcus epidermis, Staphylococcus saprophyticus bacteria, and Candida albicans fungi [1].

Earlier [5], we had reported the reducing reaction of imine hydrotropylation in the "tropylium perchloratesodium tetrahydroborate" system resulting in unstable tertiary amines, namely N-phenyl-N-arylmethyl-N-(7cyclohepta-1,3,5-trienyl)anilines. However, direction of this reaction changes after addition of imidazole to the reaction mass. Imidazole promotes a shift of the tropylium moiety from the nitrogen atom to para-position of the aniline ring and, thus, leads to formation of such stable products as N-arylmethyl-4-(7-cyclohepta-1,3,5trienyl)anilines. The educed products contain two important biogenic moieties, namely tropilidene cycle and NH-group. The NH-group - in accordance with investigations in modeling and in predicting properties of active heterocyclic compounds based on the "structure-actiontoxicity" link [6] - promotes an increase in pharmacological action and a decrease in toxicity of compounds, so important for investigations in growth control of crops.

Thus, the use of tropylium perchlorate enabled educing para-tropylated aniline [1] which had been inaccessible earlier [7], as well as secondary tropylated amines by using the ionic imine-hydrotropylation reaction [5]. A disadvantage of these methods is the use of explosive tropylium perchlorate.

\section{Results and Discussion}

Our investigation aims at the one-pot three-component synthesis of N-arylmethyl-4-(7-cyclohepta-1,3,5-trienyl) anilines by using the method [5] with tropylium tetrafluoroborate instead of explosive tropylium perchlorate.

The conducted investigation has shown that ionic hydrotropylation of imines in the "tropylium perchloratesodium tetrahydroborate" system in the presence of imidazole as activator leads to formation of $\mathrm{N}$-arylmethyl- 
4-(7-cyclohepta-1,3,5-trienyl)anilines (3a-e) with the $23.3 \%-51.4 \%$ yield (Scheme 1). It is worth noting that, in the absence of activator, the yield of tropylation products (3a-e) is only $1.5 \%-8 \%, \mathrm{~N}$-arylmethylanilines (4a-e) being the main reaction products; these results correspond with the data in [5].

Optimal ratio of reagents, namely the Schiff base: Tropylium tetrafluoroborate: Sodium tetrahydroborate: Imidazole $=1: 1: 1: 0.5$, is ascertained. The reaction proceeds at room temperature, with tetrahydrofuran as a solvent.

A role of the activator is, probably, to form the $\mathrm{B}$ complex promoting a shift of the cycloheptatriene cycle to the para-position of the aniline fragment of the A intermediate (Scheme 2).

\section{Experimental Part}

The FTIR spectra were registered by using the IR Fourier spectrometer (Bruker, Germany), registration condition: suspension in vaseline oil. The ${ }^{1} \mathrm{H}$ NMR spectra were registered by using the Mercury 300 device $(300 \mathrm{MHz})$, with hexamethyldisiloxane (HMDSO) as internal standard. Chromatograph mass spectrum was recorded by using the Agilent Technologies 6890N/597B device, the HP-5ms column $(30 \times 0.25 \mathrm{~mm}$, helium as carrier gas, ionization by $70 \mathrm{eV}$ electron shock, $100^{\circ} \mathrm{C}$ temperature of the column's thermostat, $250^{\circ} \mathrm{C}, 270^{\circ} \mathrm{C}$ temperature of evaporator); CHNS-932 (Carbon, Hydrogen, Nitrogen and Sulfur Determinator), LECO Corporation (USA).

\section{General Preparation Procedure for the 3a-e Compounds}

Imine $(1 \mathrm{mmol})$ is dissolved in $5 \mathrm{ml}$ of tetrahydrofuran, whereupon tropylium tetrafluoroborate $(1 \mathrm{mmol})$, sodium tetrahydroborate $(1 \mathrm{mmol})$, and imidazole $(0.5 \mathrm{mmol})$ are added at one go. The reaction mass is then stirred for 2.5 $\mathrm{h}$ at room temperature, diluted with water, and neutralized to $\mathrm{pH} 7$.
1) N-Benzyl-4-(7-cyclohepta-1,3,5-trienyl)aniline (3a)

The yield of the 3a compound: $0.07 \mathrm{~g}(25 \%)$, appearance: white crystals with m.p. $69^{\circ} \mathrm{C}-70^{\circ} \mathrm{C}$ (hexane), (ref. $\left.69^{\circ} \mathrm{C}-70^{\circ} \mathrm{C}[5]\right) . \mathrm{IR}$ (vas): $v_{\mathrm{NH}} 3391, \delta_{\mathrm{NH}} 1611,820 \mathrm{~cm}^{-1}$. ${ }^{1} \mathrm{H}-\mathrm{NMR}\left(\mathrm{CDCl}_{3}\right), \delta, \mathrm{ppm},(J, \mathrm{~Hz}): 2.58(1 \mathrm{H}, \mathrm{t}, J 5.4$, $\mathrm{C}^{7} \mathrm{H}$ in $\left.\mathrm{C}_{7} \mathrm{H}_{7}\right) ; 4.05$ (1 H, br.s, $\left.\mathrm{NH}\right) ; 4.34\left(2 \mathrm{H}, \mathrm{s}, \mathrm{CH}_{2}\right)$; 5.36 - $5.41\left(2 \mathrm{H}\right.$, dd, $J 5.4, \mathrm{C}^{1,6} \mathrm{H}$ in $\left.\mathrm{C}_{7} \mathrm{H}_{7}\right) ; 6.19-6.24(2$ $\mathrm{H}, \mathrm{m}, \mathrm{C}^{2,5} \mathrm{H}$ in $\left.\mathrm{C}_{7} \mathrm{H}_{7}\right) ; 6.65\left(2 \mathrm{H}, \mathrm{d}, J\right.$ 8.7, ortho- $\left.\mathrm{C}_{6} \mathrm{H}_{4}-\mathrm{NH}\right)$; $6.71-6.73\left(2 \mathrm{H}, \mathrm{m}, \mathrm{C}^{3,4} \mathrm{H}\right.$ in $\left.\mathrm{C}_{7} \mathrm{H}_{7}\right) ; 7.17(2 \mathrm{H}, \mathrm{d}, J 8.4$, meta- $\left.\mathrm{C}_{6} \mathrm{H}_{4}-\mathrm{NH}\right) ; 7.27$ - $7.40(5 \mathrm{H}, \mathrm{m}, \mathrm{Ph}) . \mathrm{MS}(\mathrm{EI})^{+}: \mathrm{m} / \mathrm{z}$ 273 (100) $[\mathrm{M}]^{+}$. Anal. Calcd for $\mathrm{C}_{20} \mathrm{H}_{19} \mathrm{~N}(273,38)$ : $\mathrm{C}$, 87.87; H, 7.00; N, 5.12. Found: C, 87.58; H, 6.95; N, 5.10 .

2) N-(4-Bromphenylmethyl)-4 ${ }^{1}$-(7-cyclohepta-1,3,5trienyl)aniline (3b)

The yield of the 3c compound: $0.26 \mathrm{~g}$ (74.3\%), appearance: white crystals with m.p. $107^{\circ} \mathrm{C}-108^{\circ} \mathrm{C}$ (hexane). ${ }^{1} \mathrm{H}-\mathrm{NMR}\left(\mathrm{CDCl}_{3}\right), \delta$, ppm, $(J, \mathrm{~Hz}): 2.59\left(1 \mathrm{H}, \mathrm{t}, J_{1,2}\right.$ 5.1, $J_{2,3} 5.4, \mathrm{C}^{7} \mathrm{H}$ in $\left.\mathrm{C}_{7} \mathrm{H}_{7}\right) ; 4.06(1 \mathrm{H}$, br.s, NH); $4.29(2$ $\left.\mathrm{H}, \mathrm{s}, \mathrm{CH}_{2}\right) ; 5.34-5.39\left(2 \mathrm{H}, \mathrm{dd}, J 5.4, \mathrm{C}^{1,6} \mathrm{H}\right.$ in $\left.\mathrm{C}_{7} \mathrm{H}_{7}\right)$; $6.19-6.23\left(2 \mathrm{H}, \mathrm{m}, \mathrm{C}^{2,5} \mathrm{H}\right.$ in $\left.\mathrm{C}_{7} \mathrm{H}_{7}\right) ; 6.65(2 \mathrm{H}, \mathrm{d}, J 8.1$, ortho- $\left.\mathrm{C}_{6} \mathrm{H}_{4}-\mathrm{NH}\right) ; 6.70-6.72\left(2 \mathrm{H}, \mathrm{m}, \mathrm{C}^{3,4} \mathrm{H}\right.$ in $\left.\mathrm{C}_{7} \mathrm{H}_{7}\right)$; $7.16\left(2 \mathrm{H}, \mathrm{d}, J 8.4\right.$, meta- $\left.\mathrm{C}_{6} \mathrm{H}_{4}-\mathrm{NH}\right) ; 7,25(2 \mathrm{H}, \mathrm{d}, J 8.1$ ortho- $\left.\mathrm{C}_{6} \mathrm{H}_{4}-\mathrm{CH}_{2}\right) ; 7.45\left(2 \mathrm{H}, \mathrm{d}, J 8.4\right.$, meta- $\left.\mathrm{C}_{6} \mathrm{H}_{4}-\mathrm{CH}_{2}\right)$. MS (EI) ${ }^{+}: \mathrm{m} / \mathrm{z} 352$ (32) $[\mathrm{M}]^{+}$. Anal. Calcd for $\mathrm{C}_{20} \mathrm{H}_{18} \mathrm{NBr}$ (352,27): C, 67.96; H, 5.05; N, 3.83. Found: C, 68.16; H, $5.15 ; \mathrm{N}, 3.97$.

3) N-(4-Chlorphenylmethyl)-4 ${ }^{1}$-(7-cyclohepta-1,3,5trienyl)aniline (3c)

The yield of the $\mathbf{3 b}$ compound is $0.25 \mathrm{~g}(83.3 \%)$, appearance: white crystals with m.p. $94^{\circ} \mathrm{C}-95^{\circ} \mathrm{C}$ (hexane), (ref. $\left.94^{\circ} \mathrm{C}-95^{\circ} \mathrm{C}[5]\right) .{ }^{1} \mathrm{H}-\mathrm{NMR}\left(\mathrm{CDCl}_{3}\right), \delta$, ppm, $(J, \mathrm{~Hz})$ : $2.59\left(1 \mathrm{H}, \mathrm{t}, J 5.4, \mathrm{C}^{7} \mathrm{H}\right.$ in $\left.\mathrm{C}_{7} \mathrm{H}_{7}\right) ; 4.07(1 \mathrm{H}$, br.s, $\mathrm{NH})$; $4.30\left(2 \mathrm{H}, \mathrm{s}, \mathrm{CH}_{2}\right) ; 5.34-5.39\left(2 \mathrm{H}, \mathrm{dd}, J 5.4, \mathrm{C}^{1,6} \mathrm{H}\right.$ in $\left.\mathrm{C}_{7} \mathrm{H}_{7}\right) ; 6.19-6.22\left(2 \mathrm{H}, \mathrm{m}, \mathrm{C}^{2,5} \mathrm{H}\right.$ in $\left.\mathrm{C}_{7} \mathrm{H}_{7}\right) ; 6.63(2 \mathrm{H}, \mathrm{d}$, $J$ 8.4, ortho- $\left.\mathrm{C}_{6} \mathrm{H}_{4}-\mathrm{NH}\right) ; 6.70-6.72\left(2 \mathrm{H}, \mathrm{m}, \mathrm{C}^{3,4} \mathrm{H}\right.$ in $\left.\mathrm{C}_{7} \mathrm{H}_{7}\right)$; $7.16\left(2 \mathrm{H}, \mathrm{d}, J\right.$ 8.4, meta- $\left.\mathrm{C}_{6} \mathrm{H}_{4}-\mathrm{NH}\right) ; 7,23$ - $7.30(4 \mathrm{H}, \mathrm{m}$,

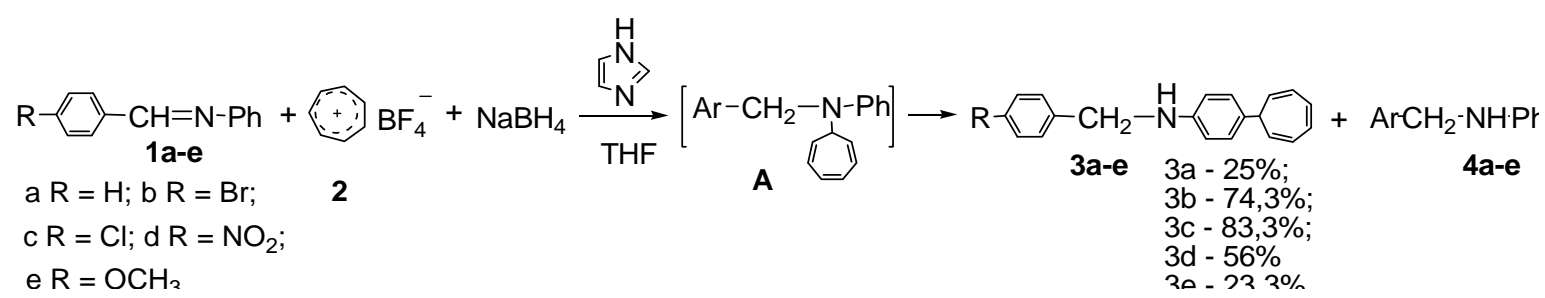

Scheme 1. One-pot synthesis of $\mathrm{N}$-arylmethyl-4-(7-cyclohepta-1,3,5-trienyl)anilines (3a-e) in the presence of imidazole.

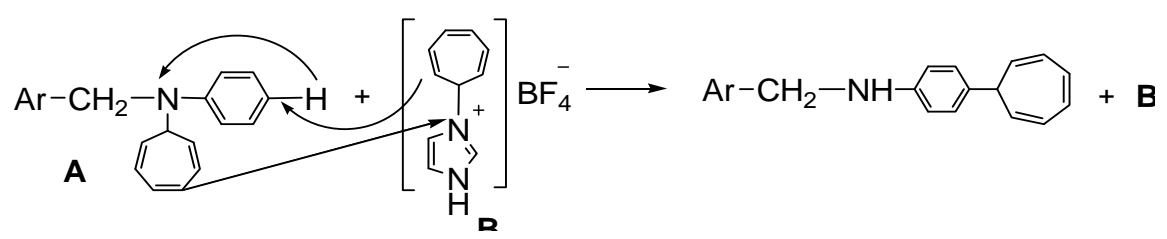

Scheme 2. The role of the $B$ complex in the reducing imine hydrotropylation process. 
Ar). MS (EI) ${ }^{+}: \mathrm{m} / \mathrm{z} 307(100)[\mathrm{M}]^{+}$. Calcd for $\mathrm{C}_{20} \mathrm{H}_{18} \mathrm{NCl}$ (307,82): C, 78.03; H, 5.89; N, 4.55. Found: C, 78.63; H, $6.00 ; \mathrm{N}, 3.44$.

4) $\mathrm{N}$-(4-Nitrophenylmethyl)-4 ${ }^{1}$-(7-cyclohepta-1,3,5trienyl)aniline (3d).

The yield of the $3 \mathbf{d}$ compound is $0.18 \mathrm{~g}(56 \%)$, appearance: white crystals with m.p. $128^{\circ} \mathrm{C}-130^{\circ} \mathrm{C}$ (hexane). ${ }^{1} \mathrm{H}-\mathrm{NMR}\left(\mathrm{CDCl}_{3}\right), \delta, \mathrm{ppm},(J, \mathrm{~Hz}): 2.59(1 \mathrm{H}, \mathrm{t}, J$ 5.1, $\mathrm{C}^{7} \mathrm{H}$ in $\left.\mathrm{C}_{7} \mathrm{H}_{7}\right) ; 4.25(1 \mathrm{H}$, br.s, $\mathrm{NH}) ; 4.48(2 \mathrm{H}$, s, $\left.\mathrm{CH}_{2}\right) ; 5.34-5.38\left(2 \mathrm{H}, \mathrm{dd}, J_{1,2} 5.4, J_{3,4} 5.7, \mathrm{C}^{1,6} \mathrm{H}\right.$ in

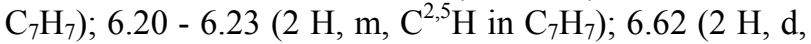
$J$ 8.7, ortho- $\left.\mathrm{C}_{6} \mathrm{H}_{4}-\mathrm{NH}\right) ; 6.69-6.72\left(2 \mathrm{H}, \mathrm{m}, \mathrm{C}^{3,4} \mathrm{H}\right.$ in $\mathrm{H}$ $\left.\mathrm{C}_{7} \mathrm{H}_{7}\right) ; 7.16\left(2 \mathrm{H}, \mathrm{d}, J\right.$ 8.4, meta- $\left.\mathrm{C}_{6} \mathrm{H}_{4}-\mathrm{NH}\right) ; 7.55(2 \mathrm{H}, \mathrm{d}$, $J$ 8.4, ortho- $\left.\mathrm{C}_{6} \mathrm{H}_{4}-\mathrm{CH}_{2}\right) ; 8.19(2 \mathrm{H}, \mathrm{d}, J$ 9.0, meta$\left.\mathrm{C}_{6} \mathrm{H}_{4}-\mathrm{CH}_{2}\right)$. MS $(\mathrm{EI})^{+}: \mathrm{m} / \mathrm{z} 318(100)[\mathrm{M}]^{+}$. Calcd for $\mathrm{C}_{20} \mathrm{H}_{18} \mathrm{~N}_{2} \mathrm{O}_{2}$ (318,37): C, 75.45; H, 5.69; N, 8.79. Found: C, 75.15; H, 5.95; N, 8.68.

5) N-(4-Methoxyphenylmethyl)-4 ${ }^{1}$-(7-cyclohepta-1,3,5trienyl)aniline (3e)

The yield of the $3 \mathrm{e}$ compound is $0.07 \mathrm{~g}(23.3 \%)$, appearance: white crystals with m.p. $73^{\circ} \mathrm{C}-74^{\circ} \mathrm{C}$ (hexane). ${ }^{1} \mathrm{H}-\mathrm{NMR}\left(\mathrm{CDCl}_{3}\right), \delta$, ppm, $(J, \mathrm{~Hz}): 2.60\left(1 \mathrm{H}, \mathrm{t}, J_{1,2} 5.4\right.$, $J_{3,4} 5.7, \mathrm{C}^{7} \mathrm{H}$ in $\left.\mathrm{C}_{7} \mathrm{H}_{7}\right) ; 3.79\left(3 \mathrm{H}, \mathrm{s}, \mathrm{OCH}_{3}\right), 3.81(1 \mathrm{H}$, br.s, $\mathrm{NH}) ; 4.26\left(2 \mathrm{H}, \mathrm{s}, \mathrm{CH}_{2}\right) ; 5.35-5.40\left(2 \mathrm{H}, \mathrm{dd}, J_{1,2}\right.$ $5.4, J_{3,4} 5.7, \mathrm{C}^{1,6} \mathrm{H}$ in $\left.\mathrm{C}_{7} \mathrm{H}_{7}\right) ; 6.20-6.23\left(2 \mathrm{H}, \mathrm{m}, \mathrm{C}^{2,5} \mathrm{H}\right.$ in $\left.\mathrm{C}_{7} \mathrm{H}_{7}\right) ; 6.65\left(2 \mathrm{H}, \mathrm{d}, J\right.$ 8.4, ortho- $\left.\mathrm{C}_{6} \mathrm{H}_{4}-\mathrm{NH}\right) ; 6.71-6.73$ $\left(2 \mathrm{H}, \mathrm{m}, \mathrm{C}^{3,4} \mathrm{H}\right.$ in $\left.\mathrm{C}_{7} \mathrm{H}_{7}\right) ; 6.88(2 \mathrm{H}, \mathrm{d}, J 8.7$, meta$\left.\mathrm{C}_{6} \mathrm{H}_{4}-\mathrm{CH}_{2}\right) ; 7.16\left(2 \mathrm{H}, \mathrm{d}, J\right.$ 8.4, meta- $\left.\mathrm{C}_{6} \mathrm{H}_{4}-\mathrm{NH}\right), 7.29(2$ $\mathrm{H}, \mathrm{d}, J$ 9.0, ortho- $\left.\mathrm{C}_{6} \mathrm{H}_{4}-\mathrm{CH}_{2}\right)$. MS (EI) ${ }^{+}: \mathrm{m} / \mathrm{z} 303$ (24) $[\mathrm{M}]^{+}$; Anal. Calcd for $\mathrm{C}_{21} \mathrm{H}_{21} \mathrm{NO}$ (303.40): C, 80.73; H, 6.57; N, 4.44. Found: C, 81.13; H, 6.97; N, 4.62.

\section{Conclusions}

Thus, the one-stage synthesis route of n-arylmethyl-4(7-cyclohepta-1,3,5-trienyl)anilines through ionic hydrotropylation of imines in the "tropylium perchlorate- sodium tetrahydroborate" system in the presence of imidazole as activator has been designed.

The advantage of this method is the use of safe-tohandle tropylium tetrafluoroborate (instead of tropylium perchlorate), and the increased yield of the $\mathbf{3 b}$-d com- pounds.

The advantage of the use of tropylium tetrafluoroborate is that higher yields for the $\mathbf{3 b - d}$ compounds are achieved as compared with tropylium perchlorate [5].

The educed compounds contain two biogenic moieties, namely $\mathrm{NH}$ group and tropilidene cycle.

\section{Acknowledgements}

This work was financially supported by the Ministry of Education of Perm Region Administration (Russian Federation).

\section{REFERENCES}

[1] L. P. Yunnikova, T. A. Akentieva, T. V. Makhova and G. A. Aleksandrova, "4-(7-Cyclohepta-1,3,5-trienyl)aniline and Derivatives Featured by Antimycobacterial Action," Butlerov Communications, Vol. 32, No. 10, 2012, pp. 22-26.

[2] L. P. Yunnikova, T. A. Akentieva, T. V. Makhova and G. A. Aleksandrova, "Synthesis and Antimicrobial Activity of Amines and Imines with a Cycloheptatriene Fragment," Pharmaceutical Chemistry Journal, Vol. 46, No. 12, 2012, pp. 106-108.

[3] K. Sanechika, S. Kajigaeshi and S. Kanemasa, "Azafulvenes; $5^{1}$. A. Facile Synthesis of 8-Azaheptafulvenes," Synthesis, Vol. 3, 1977, pp. 202-204. doi:10.1055/s-1977-24325

[4] J. J. Looker, "Alkylation of N,N-Dialkylarylamines with Tropylium Fiuoroborate," Journal of Organical Chemistry, Vol. 30, No. 12, 1965, pp. 4180-4183. doi:10.1021/jo01023a046

[5] L. P. Yunnikova and T. A. Akentieva, "Synthesis of NArylmethyl-4-(1-cyclohepta-2,4,6-trienyl)anilines," Natural and Technical Sciences, Vol. 6, No. 50, 2010, pp. 86-90.

[6] S. A. Kirlan, E. A. Kantor, A. S. Dimoglo and M. K. Vovdenko, "Regularities of the 'structure-action-toxicity' Link," Bashkirian Chemical Journal, Vol. 18, No. 2, 2011, pp. 30-34.

[7] K. Takahashi, S. Takenaka and T. Nozoe, "Cyclic CrossConjugated Hydrocarbons Having Inserted p-Quinoid Ring-I,” Tetrahedron, Vol. 30, 1974, pp. 2191-2195. doi:10.1016/S0040-4020(01)97357-0 